\title{
NEW Ravenelia SPECIES ON LEGUMINOUS HOSTS FROM THE BRAZILIAN CERRADO
}

\author{
DENISE V. REZENDE ${ }^{1} \&$ JOSÉ C. DIANESE
}

Departamento de Fitopatologia, Universidade de Brasília 70919-900, Brasília, DF

(Aceito para publicação em 03/05/2001)

Corresponding author: Denise V. Rezende

REZENDE, D.V. \& DIANESE, J.C. New Ravenelia species on leguminous hosts from the Brazilian Cerrado. Fitopatologia Brasileira 26:627-634. 2001.

\begin{abstract}
Four new Ravenelia species were described on native leguminous hosts from the Brazilian Cerrado, as follows: Ravenelia cerradensis sp. nov., $R$. chapadensis sp. nov., $R$. mineirosensis sp. nov. and $R$. emaensis sp. nov. on Chamaecrista clausenii var. cyclophylla,

Chamaecriista conferta var. virgata, Anadenanthera colubrina var. colubrina, and on Anadenanthera sp., respectively.

Key words: taxonomy, biodiversity, rust fungi, tropical fungi.

\section{RESUMO}

\section{Novas espécies de Ravenelia sobre leguminosas do Cerrado brasileiro}

Quatro espécies novas de Ravenelia foram descritas em leguminosas do Cerrado brasileiro, a saber: Ravenelia cerradensis sp. nov., $R$. chapadensis sp. nov., R. mineirosensis sp. nov. e R. emaensis sp. nov.

sobre Chamaecrista clausenii var. cyclophylla, Chamaecrista conferta var. virgata, Anadenanthera colubrina var. colubrina e Anadenanthera sp., respectivamente.
\end{abstract}

\section{INTRODUCTION}

Since 1993 the Plant Pathology Department of the University of Brasília started an extensive survey of the fungi associated with the vegetation of the Brazilian savanna, the so-called Brazilian Cerrado (Dianese et al., 1997). More than 18,500 specimens of fungi were collected in the Distrito Federal, Minas Gerais, Goiás, South Maranhão, Piauí, and Mato Grosso. Among the host families present in the Cerrado Leguminosae is the largest with 777 species followed by Compositae (Mendonça et al. 1998).

Ravenelia Berk. species are known exclusively on legumes and mostly from tropical regions (Cummins, 1978; Cummins \& Hiratsuka, 1983; Hennen et al., 1982; Hennen \& Cummins, 1990). On Cerrado an leguminous hosts, 167 fungal species were recorded comprising 61 Uredinales, which included 19 Ravenelia species (Hennen et al., 1982; Dianese et al., 1997).

Recently, a group of new Ravenelia species were described infecting leguminous hosts from the Cerrado (Hennen \& Cummins, 1990; Dianese et al. 1993). However, a wider survey remains to be done. The objective of the present work was to taxonomically study the collections of Ravenelia species deposited in the Mycological Reference Collection of

\footnotetext{
${ }^{1}$ Portion of the Doctor's thesis of the senior author
}

the University of Brasília (CMRUnB). The new taxa found are here described and illustrated.

\section{MATERIALS AND METHODS}

Leaflets of selected native leguminous from the Cerrado were collected. Each sample was prepared, numbered, registered and deposited in the Mycological Reference Collection of the University of Brasília (Herbarium UB, Mycological Collection). Slides containing squash preparations of fungal fruiting bodies or sections made by freezing microtome were used for the morphological studies and microphotography. In most cases the samples were stained with lacto-glycerol-cotton blue or glycerol$\mathrm{KOH}-$ phloxine $\mathrm{B}$ and the slides sealed with nail polish.

Pieces of leaflets with one or more lesions showing representative samples of uredia and/or telia were examined using a scanning electron microscope (SEM) after being fixed in sodium caccodylate buffer, $\mathrm{pH} 7.4,0.1 \mathrm{M}$, containing $2 \%$ glutaraldehyde, for at least $24 \mathrm{~h}$. Then followed five washes using the same buffer solution as before treatment with $1 \%$ osmium tetroxide $\left(\mathrm{OsO}_{4}\right)$ in cacodylate buffer at $4{ }^{\circ} \mathrm{C}$ for $4 \mathrm{~h}$. The samples were again washed five times with buffer solution before being dehydrated in an aqueous series with increasing acetone concentrations from 15, 30, 50, 75 and 
$100 \%$ of acetone for $15 \mathrm{~min}$ in each concentration. Leaflet pieces were then dried at the critical point before being covered with a thin layer of gold in a sputter coater for 140 seconds. Finally, the samples were observed and photographed in a Jeol SEM model JSM 840-AE (Japan).

\section{RESULTS AND DISCUSSION}

New Ravenelia species were found on Chamaecrista clausenii (Benth.) H.S. Irwin. \& Barneby var. cyclophylla (H.S. Irwin. \& Barneby) H.S. Irwin. \& Barneby, C. conferta (Benth.) H.S. Irwin. \& Barneby var. virgata H.S. Irwin. \& Barneby, on Anadenanthera colubrina (Vell.) Brenan var. colubrina, and on Anadenanthera sp. The descriptions of the new taxa are shown in the following sections.

\section{TAXONOMY}

\section{Ravenelia cerradensis Rezende \& Dianese sp. nov.}

(Figures 1. A-D; 2. A-F)

Spermogonia et aecia ignota. Uredinia $(0,2-)$ 0,3 ($0,4) \times(0,1-) 0,2(-0,3) \mathrm{mm}$, amphigena, palido brunnea, paraphysata. Paraphyses urediniorum himeniales vel peripherales, $50 \times 16 \mu \mathrm{m}$, cylindricae cum apicibus globosis vel ovoideis (18-20 $\mu \mathrm{m}$ diam.). Urediniosporae (20-) 24 (-29) $\mu \mathrm{m}$ longae x (19-) 23 (-29) $\mu \mathrm{m}$ latae, echinulatae, palido flavae; poris germinationis, 6-12, dispersis; parietis $(0,8-) 1,5(-2,0) \mu \mathrm{m}$ crassis. Telia amphigena, $(0,20-) 0,28$ $(-0,38 \times(0,13-) 0,20(-0,32) \mathrm{mm}$, subepidermalia, erumpentia, atro-brunnea, uniseriata vel biseriata circa parvis gallis disposita, paraphysata. Paraphyses teliorum idem ac paraphyses urediniorum, plerumque hymeniales. Capitula teliosporarum composita, palido-brunnea, subconidea, (60) $66(80-) \times(61-) 68(-75) \mu \mathrm{m}$, laevia, paginis strobilinis; cellulae centrales 10, (52-) 57 (-60) x (45-) 52 (56-) $\mu \mathrm{m}$; cellulae marginales 10-12, (20-) 31 (-40) x (17-) 21 (-27) $\mu \mathrm{m}$. Cystae 8-10, (15-) 21 (-25) x (15-) 21 (-27) $\mu \mathrm{m}$, hyalinae, uniseriatae, pendentes, globosae vel ovoideae. Pedicelli persistentes, 4-6 filis hyphalis composita.

Holotypus: in foliis vivis Chamaecristae clauseniorum var. cyclophyllae Irwing \& Barneby (= Cassiae clauseniorum var. cyclophyllae); $4.1 \mathrm{~km}$ via Chapada dos Guimarães ad Morro São Gerônimo, Parque Nacional Chapada dos Guimarães, Chapada dos Guimarães, MT; M. Sanchez, ${ }^{\circ}$ 2448; 20 V 1997; UB Col. Mycol. 13781.

Spermogonia and aecia not observed. Uredinia $(0,2-)$ $0,3(-0,4) \times(0,1-) 0,2(-0,3) \mathrm{mm}$, amphigenous, light brown, paraphysate. Paraphyses hymenial or peripheral, $50 \mu \mathrm{m}$ long x $4 \mu \mathrm{m}$ wide, cylindrical with globoid to ovoid tips (18-20 $\mu \mathrm{m}$ diam.) (Figure 1A,B); Urediniospores (20-) 24 (-29) $\mu \mathrm{m}$ long x (19-) 23 (-29) $\mu \mathrm{m}$ wide, echinulated, yellowish, with scattered 6-12 germpores, thick walled; walls (0,8-) 1,5 $(-2,0) \mu \mathrm{m}$ thick (Figure 1B,C). Telia amphigenous, (0,20-) $0,28(-0,38 \times(0,13-) 0,20(-0,32) \mathrm{mm}$, subepidermal, erumpent, dark brown, forming rows around small galls, covered by a thin membrane (Figure 2A,B), paraphysate. Paraphyses mostly hymenial similar to uredinial paraphyses (Figure 2D). Teliospores compound, light brown, forming teliospore heads, (60-) 66 (80-) x (61-) 68 (-75) $\mu \mathrm{m}$, smooth, tending to a subconical shape (Figure $2 \mathrm{E}$ ); central cells 10 , (52-) 57 (-72) x (45-) 52 (-70) $\mu \mathrm{m}$, (Figures 2C,E), 8-10 rusty yellow; marginal cells (20-) 31 (-40) x (17-) 21 (-27) $\mu \mathrm{m}$. Cysts 8-10, hyaline, uniseriate, hydrophylic, globoid to ovoid (15-) 21 (-25) x (15-) $21(-27) \mu \mathrm{m}$, pendants. Pedicel persistent, compound, consisting of 4-6 hyphal strands (Figure 2F).

Several Cassia sensu lato (s.l.) species are presently accommodated in Chamaecrista Moench. and Senna Mill. (Lewis, 1987). Thus, when comparing Ravenelia species infecting Chamaecrista spp. all previous records of the fungus on Cassia and Senna have to be considered in the discussion.

Sydow \& Sydow (1915) described 15 known Ravenelia species on Cassia s.l. Among them 10 species showed aparaphysate telia. Thus all five remaining paraphysate species $[R$. mesillana Ellis \& Barth. (=R. longiana Syd. \& P. Syd.), R. spinulosa Diet. \& Holw. var. papillifera (Syd. \& P. Syd.) Cumm. \& J.W. Baxt. (=R. papillifera Syd. \& P. Syd.), $R$. spinulosa Dietel \& Holw., $R$. macrocarpa Syd., and $R$. testui Maubl.] will be discussed because some of the Cassia spp. reported as host could now belong in Chamaecrista. Among those five species only $R$. macrocarpa which has also been listed in Hennen et al. (1982)

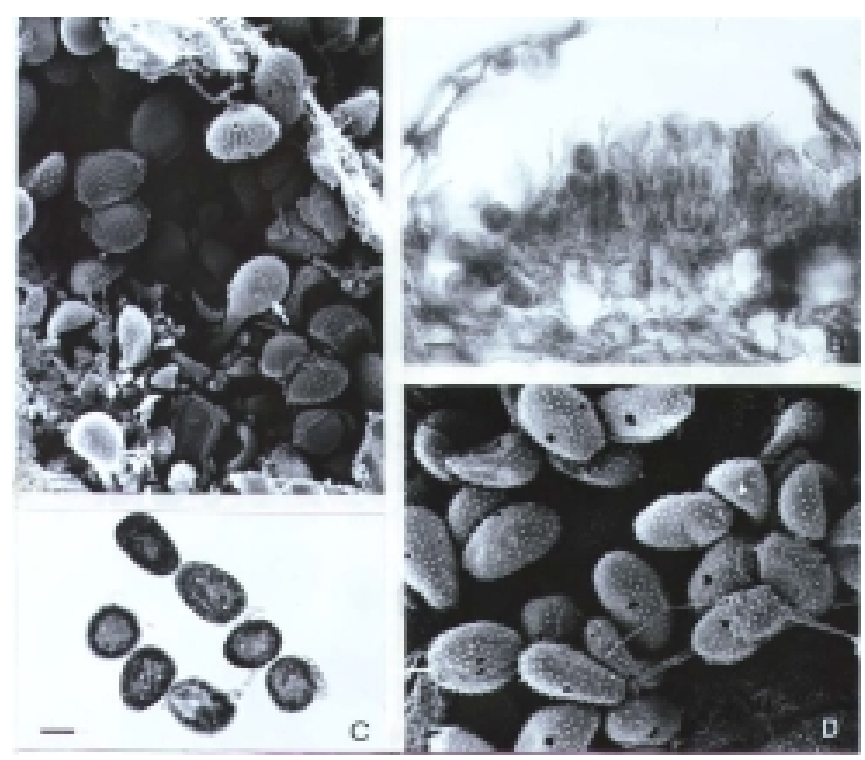

FIG. 1 - Ravenelia cerradensis on Chamaecrista clausenii var. cyclophylla, uredinial phase. A- Uredinia with urediniospores and parahyses (arrow) seen in SEM. B- Section of a paraphysate, subepidermal, erumpent uredinia seen in OM. CDetails of urediniospores showing sparse germ pores and thick wall. D- Echinulate urediniospores, showing germ pores seen in SEM. Bars: $A, C=10 \mu \mathrm{m} ; B=20 \mu \mathrm{m}$; and $D=5 \mu \mathrm{m}$. 
shows teliospores which are not superficially papillate or tuberculate as in this new species. However, R. macrocarpa shows subcuticular uredinia instead of subepidermal sori. It also shows teliospore heads with a more elliptical surface reaching a length of $140 \mu \mathrm{m}$ while $R$. cerradensis sp. nov. shows heads which are more globoid (an average of $66 \times 68$ $\mu \mathrm{m})$. Ravenelia spinulosa $\mathrm{v}$. papillifera has papillate marginal cell, $R$. mesillana forms multiseriate cysts, and showed only paraphysate uredinia. Finally in $R$. testui all of the teliospores are unipapillate not smooth as in the new species. Thus, all five species are different from $R$. cerradensis sp. nov.

Furthermore, Hennen et al. (1982) mentioned R. faceta H.S. Jacks. \& Holw. another species with paraphysate sori on Cassia in Brazil. However, this species differs from $R$. cerradensis due to smaller $(45-60 \mu \mathrm{m})$ tuberculated teliospores.

More recently Hennen \& Cummins (1990) described 15 Ravenelia species being ten from Brazil. Among those, two were found on Senna species ( $R$. densifera Henn. \& Cumm.

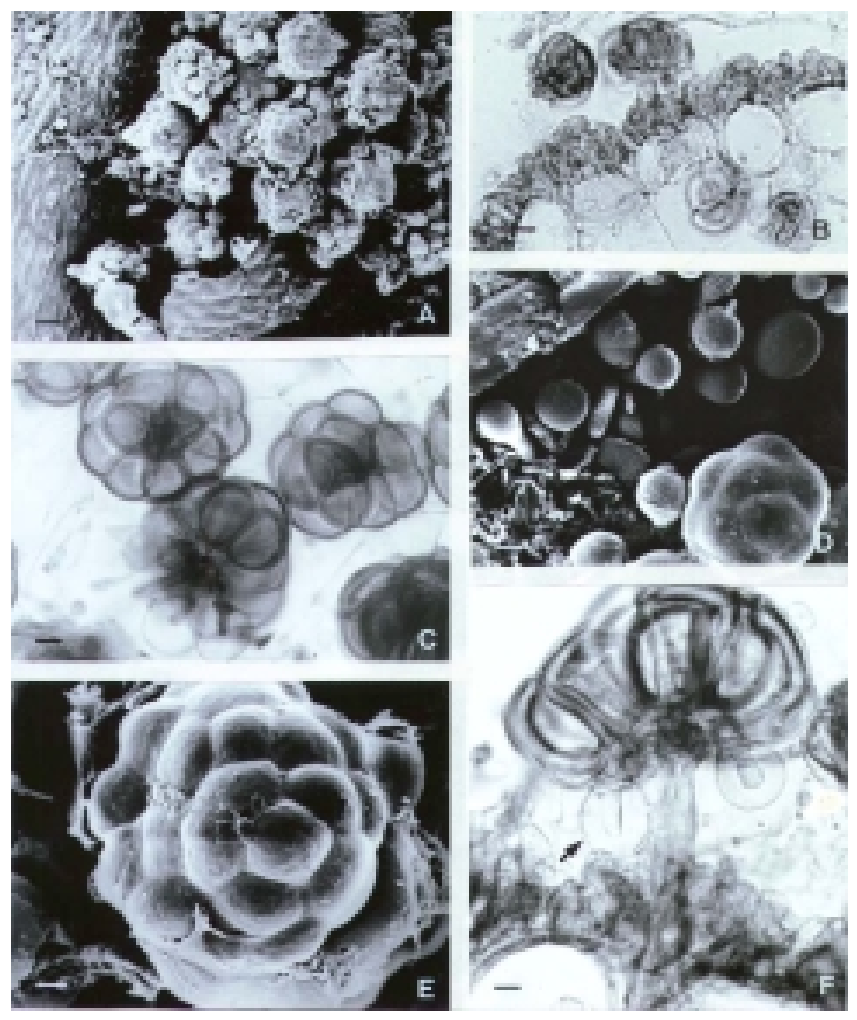

FIG. 2 - Ravenelia cerradensis on Chamaecrista clausenii var. cyclophylla, telial phase. A- Subepidermal, erumpent telium, showing teliospore heads with ondulate surface, seen on SEM. B- Section of a telium showing teliospore heads. $\mathrm{C}$ - Teliospore heads with hygroscopic cysts. D- A teliospore head and clavate telial paraphyses, seen on SEM. E- Upper surface of a teliospore head. F-Section through a teliospore head showing individual cell components, pendent cysts (arrow) and compound hyphalic pedicel. (Bars: A, B $=20 \mu \mathrm{m} ; C, D=10$ $\mu \mathrm{m} ; \mathrm{E}, \mathrm{F}=\mathbf{5} \mu \mathrm{m})$. and $R$. eminens Henn. \& Cumm.) both with aparaphysate telia and producing highly tuberculate teliospores. The other species in Hennen \& Cummins (1990) were found on hosts not related to Cassia s.l. all of them showing major differences from the new species and thus do not require a comparison with $R$. cerradensis sp. nov. This is also the case of the following species collected in Brazil: $R$. corbuloides Henn. \& Cumm., R. geminipora Henn. \& Cumm., $R$. lata Henn. \& Cumm., $R$. pernigra Henn. \& Cumm., $R$. septata Henn. \& Cumm., R. spiralis Henn. \& Cumm., $R$. tessellata Henn. \& Cumm., and R. tortuosa Henn. \& Cumm.

Based on the discussion above it becomes clear that the specimen described belongs to a new Ravenelia species, now designated $R$. cerradensis sp. nov.

\section{Ravenelia chapadensis Rezende \& Dianese, sp. nov. \\ (Figures 3 A-F; 4. A-F)}

Spermogonia et aecia ignota. Uredinia parva, (30-) $50(-75) \times(28-) 35(-50) \mu \mathrm{m}$, amphigena, subepidermalia, erumpentia, palido brunnea, aliquando teliosporae formantes, paraphysata. Paraphyses hymeniales, abundantes, cylindricae vel clavatae, usque ad $50 \mu \mathrm{m}$ longis x $5 \mu \mathrm{m}$ diam; Urediniosporae rubiginoso flavae, obovoideae vel ovoideae, (23-) $27(-30) \mathrm{x}$ (16-) 20 (-23) $\mu \mathrm{m}$, parietibus crassis; poris germinationis $8-12$, dispersis; parietes $2-2,5 \mu \mathrm{m}$ crassi. Telia amphigena, subepidermalia, erumpentia, parva, (38-) 59 (-100) x (-25) $40(-63) \mu \mathrm{m}$. (Figure 2E). Capitula teliosporarum composita, hemisphaerica vel subconoidea, pedicellata, palido-brunnea, (101-) 131 (-144) x (94-) 107 (-139) $\mu \mathrm{m}, 6-12$ cellulis diametro constituta; pagina capitulorum irregularis foveatis vel foveolatis; parietibus $2-3 \mu \mathrm{m}$ crassis; cellulae centrales 8 10, (15-) 24 (-39) x (13-) 18 (-29) $\mu \mathrm{m}$ diam, cylindricae, perimetris paginarum hexagonalis; cellulae marginales $8-12$, (30-) $35(-40) \times(13-) 18(-29) \mu \mathrm{m}$, cylindricae, perimetris paginarum retangularis, basibus cum lamina cellularum intercalaris connectis. Cellulae intercalares 8-12, cylindricae vel leviter clavatae, (8-) $12(-14) \times(5-) 7(-8) \mu \mathrm{m}$, basibus cellularum marginalium cystae et pedicelli connectis. Cystae 25-30, (18-) 24 (17-)(-28), pendentes vel semipendentes, cellulis intercalaribus connectis. Pedicelli (40-) 80 (-120) x (12-) 20 (22) $\mu \mathrm{m}$, multihyphalici, ex 8-10 fili hyphalici compositi, semipersistentes, ad apicem cellulis intercalaribus connecti.

Holotypus: in foliis vivis Chamaecristae decumbentes (Benth.) H.S. Irwin. \& Barneby: prope Parque Nacional da Chapada dos Veadeiros, GO, M. Sanchez no. 259, 17 X 1994, UB Col. Mycol. 6669.

Isotypus: in foliis vivis Chamaecristae decumbentes (Benth.) H.S. Irwin. \& Barneby: Parque Nacional da Chapada dos Veadeiros, ex agro humido, $2 \mathrm{~km}$ ab Alto Paraíso via Parque Nacional, Alto Paraíso, GO, J.C. Dianese nº. 1862, 16 X 1994, UB Col Mycol. 6692.

Spermogonia and aecia unknown. Uredinia small (30-) $50(-75) \times(28-) 35(-50) \mu \mathrm{m}$, amphigenous, subepidermal in origin, erumpent, light brown, paraphysate, sometimes also 
containing teliospores. (Figures 3A,B). Paraphyses hymenial, abundant, cylindrical to clavate, up to $50 \mu \mathrm{m}$ long x $5 \mu \mathrm{m}$ diam. (Figures 3C,D,E); Urediniospores rusty yellow, obovoid to ovoid (23-) $27(-30) \times(16-) 20(-23) \mu \mathrm{m}$, with 8-12 scattered germ pores, thick walled; wall $2-2,5 \mu \mathrm{m}$ thick (Figure 3F). Telia amphigenous, subepidermal, erumpent, paraphysate, small (38-) $59(-100) \times(-25) 40(-63) \mu \mathrm{m}$ (Figure 4B). Teliospore heads pedicellate, compound, irregular to flat surface, (101-) 131 $(-144) \times(94-) 107(-139) \mu \mathrm{m}, 6-12$ cells across, irregular, with foveate or lightly pitted surface (Figures 4A,E); with 2-3 $\mu \mathrm{m}$ thick wall; central cells, 8-10, cylindrical with an hexagonal superficial profile, (15-) 24 (-39) x (13-) 18 (-29) $\mu \mathrm{m}$ diam.; marginal cells $8-12$, cylindrical with a rectangular superficial profile (30-) 35 (-40) x (13-) 18 (-29) $\mu \mathrm{m}$., connected to a layer of 8-12 cylindrical to slightly clavate intercalary cells. Intercalary cells (8-) 12 (-14) x (5-) 7 (-8) $\mu \mathrm{m}$, bearing the marginal cells and connected to the cysts and the pedicels on the lower face (Figures 4C,D,E). Cysts 25-30, (18-) $24(-30) \times(17-) 21(-28) \mu \mathrm{m}$, pendent or semipendent, connected to the intercalary cells. Pedicells $(40$ ) $80(-120) \times(12-) 20(-22) \mu \mathrm{m}$, multihyphal, with $8-10$ hyphal components, semipersistant, connected to the intercalary cells at the top (Figures 4E,F).

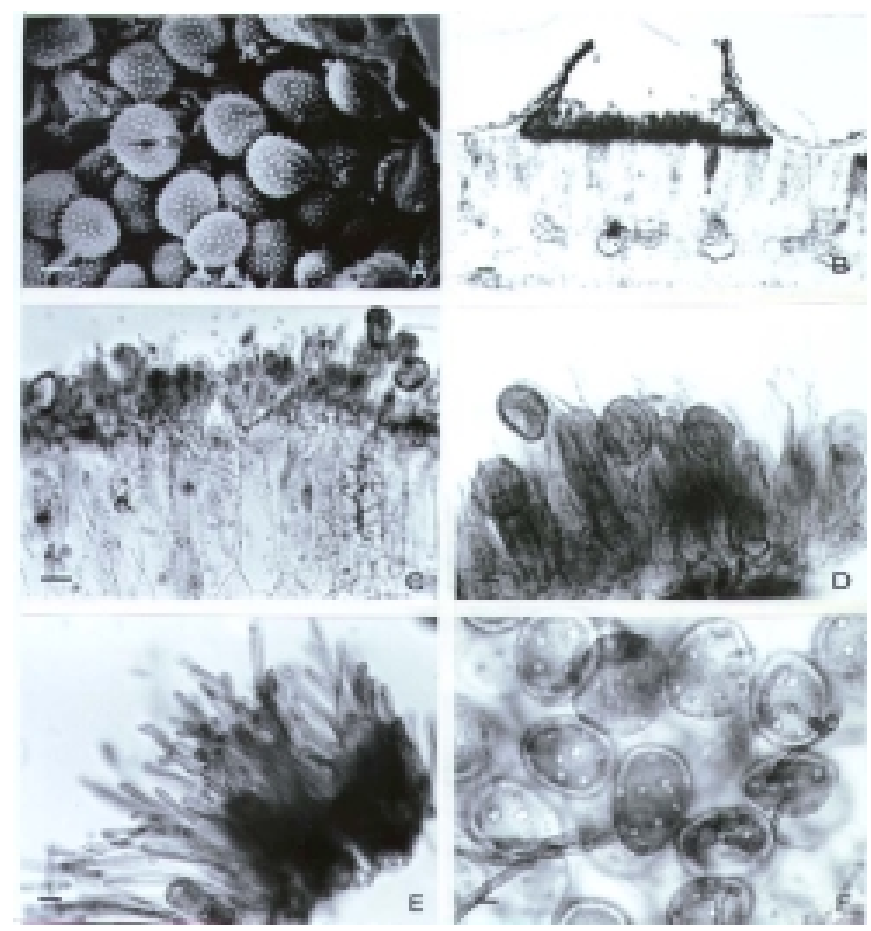

FIG. 3 - Ravenelia chapadensis on Chamaecrista conferta, uredinial phase. A- A mass of echinulate urediniospores and hymenial paraphyses (arrow). B- Section through an erumpent, subepidermal uredinium. C, D- Detailed view of paraphysate uredinia. E- Cylindrical paraphyses seen on OM. F- Urediniospores showing thick wall and scattered germ pores. Bars: $A$ and $D=10 \mu \mathrm{m}$; $B$ $=60 \mu \mathrm{m} ; \mathrm{C}=20 \mu \mathrm{m} ; \mathrm{E}$ and $\mathrm{F}=5 \mu \mathrm{m}$.
Other specimens examined: on living leaves of Chamaecrista conferta (Benth.) H.S. Irwin. \& Barneby var. virgata H.S. Irwin. \& Barneby; "Parque Nacional da Chapada dos Veadeiros", "Trilha das Cachoeiras", "Alto Paraíso, GO”, 15, X, 1994, J.C. Dianese no. 1828, UB Col. Mycol. 6624; "Estação Ecológica das Águas Emendadas, Planaltina, DF, 14, III, 1995, M. Sanchez n. 2765, UB Col. Mycol. 14564”.

This new species shows all the characteristics of Ravenelia such as compound multicellular teliospore heads, containing central and marginal cells, bearing cysts below and showing a multihyphal pedicels. The urediniospores show scattered germ pores. However, the specimen studied also shows an intercalary layer of cells connecting the marginal
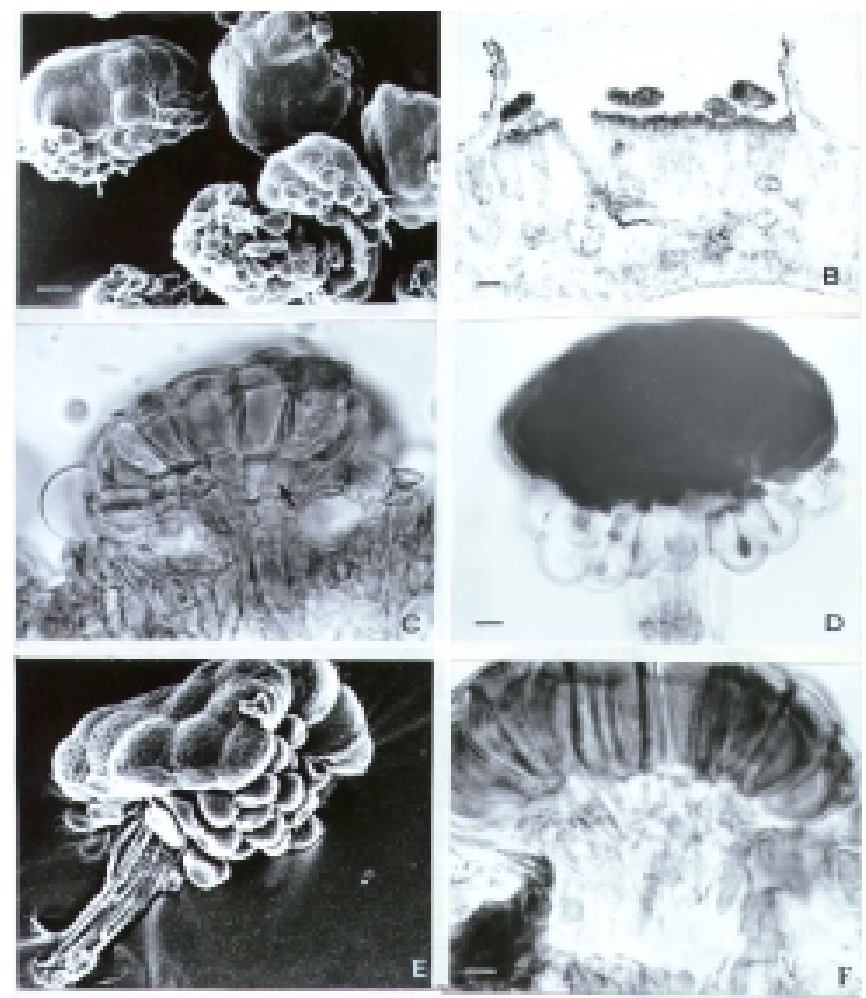

FIG. 4 - Ravenelia chapadensis on Chamaecrista conferta, telial phase. A-Teliospore heads with large numbers of subjacent semi-adherent cysts seen on SEM. B- Section showing subepidermal condition of a telium. C- Teliospore head showing intercalary cells that compose the compound teliospore with layers of intercalary cells (arrow) forming a layer which connects the teliosporic layer with the cysts and the multihyphal pedicel. D- A teliospore head showing a group of 10 cysts and a multicomponent hyphalic pedicel. EDetails of a teliospore head with wavy surface, showing also cysts and compound pedicel. FSection of a teliospore head showing individual cells, intercalary layer and cysts. Bars: $A=\mathbf{2 0}$ $\mu \mathrm{m} ; \mathrm{B}=60 \mu \mathrm{m} ; \mathrm{C}, \mathrm{D}, \mathrm{E}, \mathrm{F}=10 \mu \mathrm{m}$. 
cells with the pedicel and the cysts. This is a cell layer and is an attribute of the genus Kernkampella Rajendren, specifically pathogenic to Euphorbiaceae (Rajendren, 1970). However, the new species shows teliospores with a foveate surface instead of one that is strongly tuberculate as in Kernkampella species. Furthermore, the new species forms urediniopores holoblastically and not in a repetitive manner as in Kernkampella.

Thus all specimens here studied belong in the genus Ravenelia and due to the intercalary cells shown they surely belong in a very restricted group of species. Thus, $R$. chapadensis sp. nov. with irregularly shaped teliospore heads is clearly different from all paraphysate species already compared to $R$. cerradensis sp. nov. The only species reported as having an intercalary layer of cells separating the spores from the cysts is $R$. opaca Diet. (Dietel, 1895) as indicated by Cummins \& Hiratsuka (1983). However, the original descriptions of $R$. opaca included in Sydow \& Sydow (1915) and also in Cummins (1978) do not mention the existence of cells between cysts and teliospore. In $R$. opaca telia are very large and may reach $3 \mathrm{~mm}$ diam but teliospore heads do not reach $140 \mu \mathrm{m}$ as in the new species. Finally the teliospores of $R$. opaca have a smooth surface while those of $R$. chapadensis sp. nov. show slight pitting all over their surface. Sydow \& Sydow (1915) and Cummins (1978) did not mention uredinia and urediniospores which, however, are always present in this new species. On the other hand spermogonia were not found in $R$. chapadensis sp. nov. but were present in $R$. opaca (Sydow \& Sydow, 1915; Cummins, 1978).

Multiseriate abundant ( 25 to 30 cysts per teliospore head) cysts, the presence of intercalary cells in larger teliospores, are characteristics sufficient to separate $R$. chapadensis sp. nov. from $R$. cerradensis sp. nov.

\section{3 - Ravenelia mineirosensis Rezende \& Dianese sp. nov. (Figures 5. A-D; 6. A-E)}

Etymology: after Mineiros, a city of the State of Goiás close to the site where the type was collected.

Spermogonia et aecia ignota. Uredinia (33-) 55 (95) x (33-) 38 (-63) $\mu \mathrm{m}$, hypophylla, subepidermalia, erumpentia, cinnamomo-brunnea, paraphysata; paraphyses 48-52 $\mu \mathrm{m} \times 4-6 \mu \mathrm{m}$, saepe peripherales, cylindricae vel clavatae, aureo-brunneae, apicibus 16-10 x 15-17 $\mu \mathrm{m}$ diam., gobosisis vel obovoideis. Urediniosporae (17-) 23 (-28) x (14-) 15 (-18) $\mu \mathrm{m}$, palido-brunneae, obovoideae vel ellipsoideae, 4-6 poris germinationis dispersis saepe equatoriales vel subequatoriales, parietibus lateralibus $2 \mu \mathrm{m}$ crassis, parietibus apicalibus $2-3 \mu \mathrm{m}$ crassis, parietibus basalibus $1.5-2 \mu \mathrm{m}$ crassis, omnino valde echinulatae; echinulationes conicae, 5-7 $\mu \mathrm{m}$ longae. Telia (50-) $75(-100) \times(33-) 50(-70) \mu \mathrm{m}$, amphigena, saepe hypophylla, rubinoso-brunnea, subepidermalia, erumpentia, paraphysata. Paraphyses similem paraphyses urediniarum, plerumque peripherales,. Capitula teliosporarum (85-) 96 (-110) x (86-) 91 (-110) composita, discoidea vel hemisphaerica, pedicellata, palido brunnea, 5-7 cellulis diametro constituta, pagina capitulorum laevia; parietibus 3-
$4 \mu \mathrm{m}$ crassis; cellulae centrales $4,(15-) 18$ (-20) $\mu \mathrm{m}$ diam, perimetris superis cellularum pentagonalis et crassiatis; cellulae marginales 6-8, (17-) 22 (-25) $\mu \mathrm{m}$, cylindricae, perimetris paginarum retangularis, laeviae, basibus cellularum marginales cystae et pedicelli connectis; parietes 3-4 $\mu \mathrm{m}$ crassis. Cystae 6-8, saepe 8, (17-) 19 (-20) $\mu \mathrm{m}$, pendentes. Pedicelli 16 × $6 \mu \mathrm{m}$, multihyphalici, descidui.

Holotypus: in foliis vivis Anadenantherae colubrinae (Vell.) Brenan var. colubrinae; "Parque Nacional das Emas", in agro gramineo, Mineiros, GO, 13 IV 1997, M. Sanchez 2657, UB Col. Micol. 14369.

Isotypus: in foliis vivis Anadenantherae colubrinae (Vell.) Brenan var. colubrinae; Parque Nacional das Emas, via flumen Jacuba, Mineiros, GO, 11 IV 1997, Pfenning 102, UB Col. Micol. 14258.

Spermogonia and aecia unknown. Uredinia (33-) 55 (-95) x (33-) 38 (-63) $\mu \mathrm{m}$ hypophyllous, subepidermal, erumpent, cinnamon-brown (Figures 5A,B). Paraphyses 48$52 \mu \mathrm{m}$ long $\mathrm{x} 4-6 \mu \mathrm{m}$ wide, clavate with globoid to obovoid tips (16-) $18(-20) \times(15-) 16(-17) \mu \mathrm{m}$, mostly peripheral, golden-brown (Figures 5B,C). Urediniospores (17-) 23 (28) $\mathrm{x}(14-) 15(-18) \mu \mathrm{m}$, ellipsoid to obovoid, strongly echinulate; echinulations conical, 5-7 $\mu \mathrm{m}$ high, with a depressed halo around of the base (Figure 5D); wall $2 \mu \mathrm{m}$

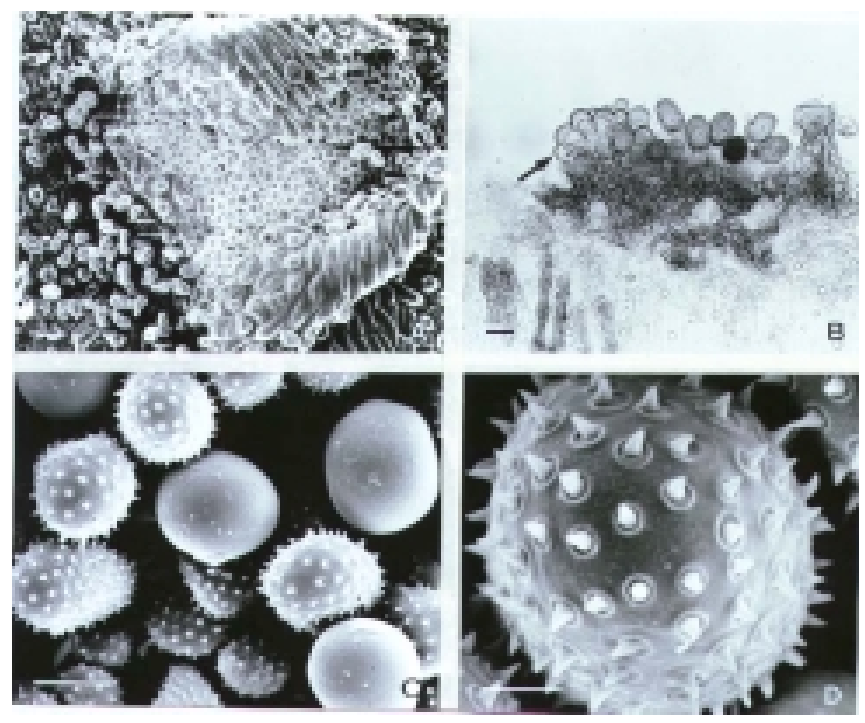

FIG. 5 - Ravenelia mineirosensis on Anadenanthera colubrina var. colubrina, uredinial phase. ASubepidermal hypophyllous uredinium. BSection through an uredinium showing peripheral paraphyses (arrow) and urediniospores, with equatorial germ pores. $\mathrm{C}-$ Echinulate urediniospores and clavate smooth paraphyses with globose tip. D-Details of an urediniospore seen on SEM with a clear halo around the base of the echinulations. Bars: $A$, $B=20 \mu \mathrm{m}, C=10 \mu \mathrm{m}$ and $\mathrm{D}=\mathbf{5} \mu \mathrm{m}$. 
thick at the sides, $2-3 \mu \mathrm{m}$ at the spore apex and 1,5-2 $\mu \mathrm{m}$ at the base; germ pores 4-6, scattered, mostly equatorial and subequatorial. Telia (50-) $75(-100) \times(33-) 50(-70)$ $\mu \mathrm{m}$, amphigenous, mostly hypophyllous, rusty-brown, paraphysate as uredinia; paraphyses mostly peripheral (Figures 6A,B). Teliospore heads (85-) 96 (-110) x (86-) $91(-110) \mu \mathrm{m}$, smooth, 5-7 seven cells across; central cells 4, pentagonal, (17-) 18 (-20) x (15-) $18(-20) \mu \mathrm{m}$, with prominent lines around each cell; marginal cells $6-8$ rectangular, smooth, (17-) $22(-25) \mu \mathrm{m}$; walls $3-4 \mu \mathrm{m}$ thick (Figures 6C,D). Cysts 6-8, mostly 8, globoid, (18-) 19 (-20) $\mathrm{x}(17-) 18(-20) \mu \mathrm{m}$, hygroscopic, pendent (Figure 6E). Pedicels multihyphal, 16 x $6 \mu \mathrm{m}$, not persistent.

Several leguminous species belonging in Piptadenia Benth. were recombined in Anadenanthera Speg. (Lewis, 1987). Thus the Ravenelia species previously reported on the Piptadenia species were compared with this new species here described because there is no record of a Ravenelia species infecting Anadenanthera. According to Sydow \& Sydow (1915) the Ravenelia spp. found on the Piptanenia

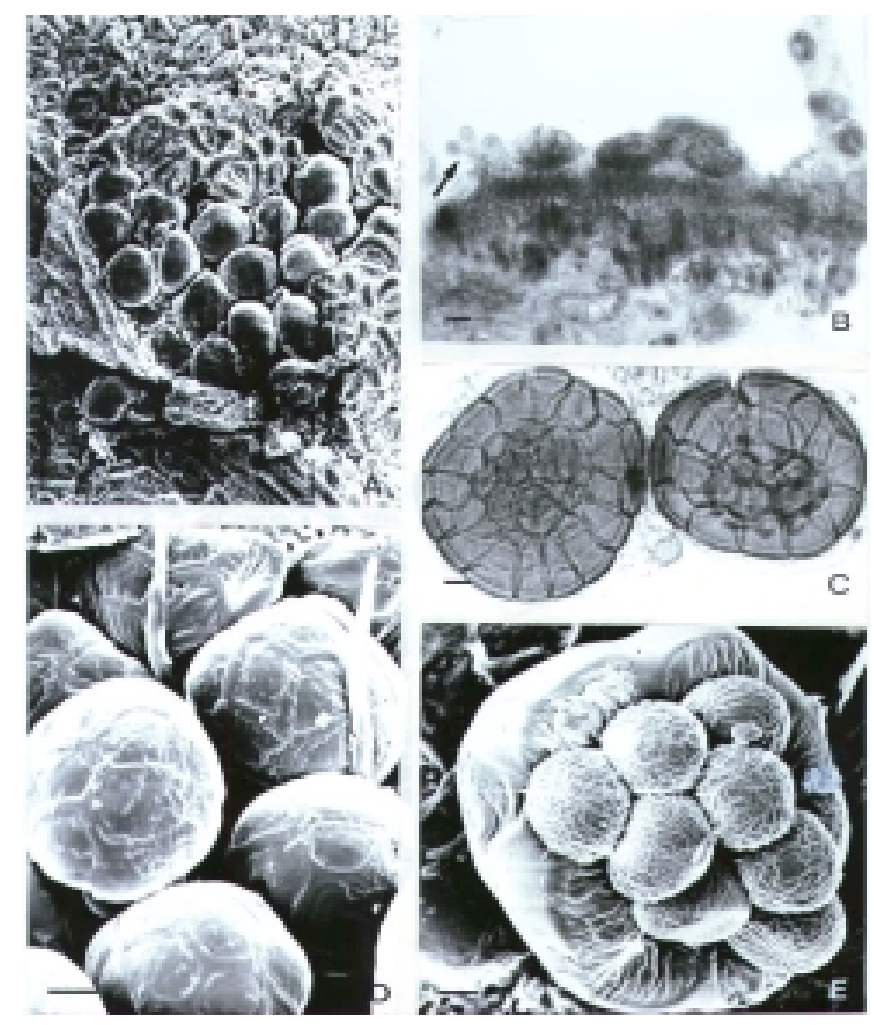

FIG. 6 - Ravenelia mineirosensis on Anadenanthera colubrina var. colubrina, telial phase. AErumpent epiphylous telium. B-Section through a telium showing peripheral paraphyses (arrow) and teliospore heads. C- Two smooth teliospore heads, showing central and marginal cells. DFour teliospore heads, with central cells bound by conspicuous prominent walls. E- Teliospore head with eight pendent cysts. Bars: $A=\mathbf{4 0} \mu \mathrm{m}$; $B=30 \mu \mathrm{m} ; C$ and $E=10 \mu \mathrm{m}$, and $D=20 \mu \mathrm{m}$. species are: $R$. henningsiana Diet. on Piptadenia sp., $R$. simplex Diet. on $P$. stipulacea (Benth.) Ducke. (=P. communis Benth.), and $R$. cebil Speg. on Anadenanthera colubrina (Vell.) Brenan var. cebil (Gris.) Alts. (= P. macrocarpa Benth. var. cebil (Gris.) Chad. \& Hass). Hennen et al. (1982) listed R. henningsiana, R. simplex, and Uredo vilis (Syd. \& P. Syd.) Baxter (= R. vilis Syd. \& P. Syd.) (Baxter, 1975; Sydow \& Sydow, 1916) as the Ravenelia species occurring in Brazil.

The new Ravenelia species on Anadenanthera was compared with other smoothly-teliospored species found on this host genus and also with those four species parasitic on Piptadenia spp (Ravenelia emaensis sp. nov. on Anadenanthera sp.; $R$. simplex on $P$. communis; $R$. henningsiana on Piptadenia sp.; $R$. cebil on P. macrocarpa and Uredo vilis on Piptadenia sp.).

Uredo vitis with two germ pores in its thin-walled urediniospores is not the uredinial phase of $R$. mineirosensis sp. nov. which shows thick-walled spores with 4-6 germ pores. Ravenelia simplex clearly differs from $R$. mineirosensis sp. nov. based on size and shape of the teliospores. Neither R. henningsiana with epiphyllous aparaphysate telia and uredinia, and tuberculate smaller teliospores, nor $R$. sydowiana with aparaphysate telia can not be confused with the new species. Ravenelia chacoensis reported from Argentina (Lindquist, 1946) shows shorter paraphyses $(30 \mu \mathrm{m})$ and at least seven central cells in the teliospore head, a number much higher than four central cells found in $R$. mineirosensis which forms $52 \mu \mathrm{m}$ long paraphyses. Finally, $R$. cebil described as another variety of Anadenanthera colubrina (= Piptadenia macrocarpa) showing 3-5 ovoid cysts and amphigenous uredia is also different from this new fungus which forms 6-8 globoid, cysts and shows only hypophyllous uredinia.

Thus, this discussion leads to the conclusion that the fungus here described belongs to a new species which is designated $R$. mineirosensis sp. nov.

\section{4 - Ravenelia emaensis Rezende \& Dianese sp. nov.} (Figures 7. A-E; 8. A-F)

Spermogonia et aecia ignota. Uredinia (55-) 58 (62) x (15-) 19 (-22) $\mu \mathrm{m}$, hypophylla, subepidermalia, erumpentia, cinnamomo-brunnea, paraphysata; paraphyses 40-50 $\mu \mathrm{m}$ long, saepe peripherales, clavatae, aureo-brunneae, apicibus globosis vel ovoideis usque ad $7 \mu \mathrm{m}$ diam. Urediniosporae (22-) 27 (-30) x (10-) $13(-15) \mu \mathrm{m}$, palidobrunneae, obovoideae, clavatae vel pyriformes, echinulatae, 2-4 poris germinationis, saepe 3 , equatorialibus unizonatis; echinulationes cylindricae, 4-5 $\mu \mathrm{m}$ longae. Telia (14-) 22 (24) x (12-) $17(-24) \mu \mathrm{m}$, hypophylla, aliquando urediniosporae formantes, erumpentia, paraphysata, paraphyses similem paraphyses urediniarum. Capitula teliosporarum (89-) $96(-110) \times(82-) 88(-110) \mu \mathrm{m}$, composita, perimetro irregulari vel circulari, pedicellata, aurantico-brunnea, 6-7 cellulis diametro constituta, pagina capitulorum laevia; parietibus apicalibus 5-6 $\mu \mathrm{m}$ crassis; parietibus lateralibus $0.5-1 \mu \mathrm{m}$ crassis; cellulae centrales cells 
9-12, (21-) 23 (-26) x (17-) 19 (-21) $\mu$ m diam, perimetris superis cellularum hexagonalis; cellulae marginales 18-24, (18-) 23 (-27) x (-10) 14 (-17) $\mu \mathrm{m}$. Cystae 18-24, globosae, 18-16 $\mu \mathrm{m}$ diam., hyalinae, appressae. Pedicelli $30 \times 14 \mu \mathrm{m}$, multihyphalici, ex 4-6 fili hyphali compositi, descidui.

Holotypus: in foliis vivis Anadenantherae sp., Parque Nacional das Emas, via flumen Jacuba, Mineiros, GO, L. Pfenning no. 102, 12 IV 1997, UB Col. Mycol. 14258.

Spermogonia and aecia unknown. Uredinia (55-) 58 (-62) x (15-) 19 (-22) $\mu \mathrm{m}$, hypophyllous, subepidermal, erumpent, cinnamon-brown, paraphysate; paraphyses orange-rusty, 40-50 $\mu \mathrm{m}$ long, with ovoid or globose tips, up to $7 \mu \mathrm{m}$ diameter (Figures 7A,B). Urediniospores (22-) $27(-30) \times(10-) 13(-15) \mu \mathrm{m}$, obovoid, clavate to piriform, pale brown, with cylindrical echinulations 4 $5 \mu \mathrm{m}$ long, 2-4 germ pores, often three; pores equatorial, unizonate (Figures 7C,D,E). Telia (14-) 22 (-24) x (12-) $17(-24) \mu \mathrm{m}$, hypophyllous, sometimes also forming urediniospores, paraphysate (Figures 8A,B,C); paraphyses same as those of the uredinia. Teliospores compound, multicellular, (89-) $96(-110) \times(82-) 88(-110) \mu \mathrm{m}$, with perimeter irregular or round, 6-7 cells across, smooth, orange-rusty; central cells 9-12, with hexagonal perimeter,

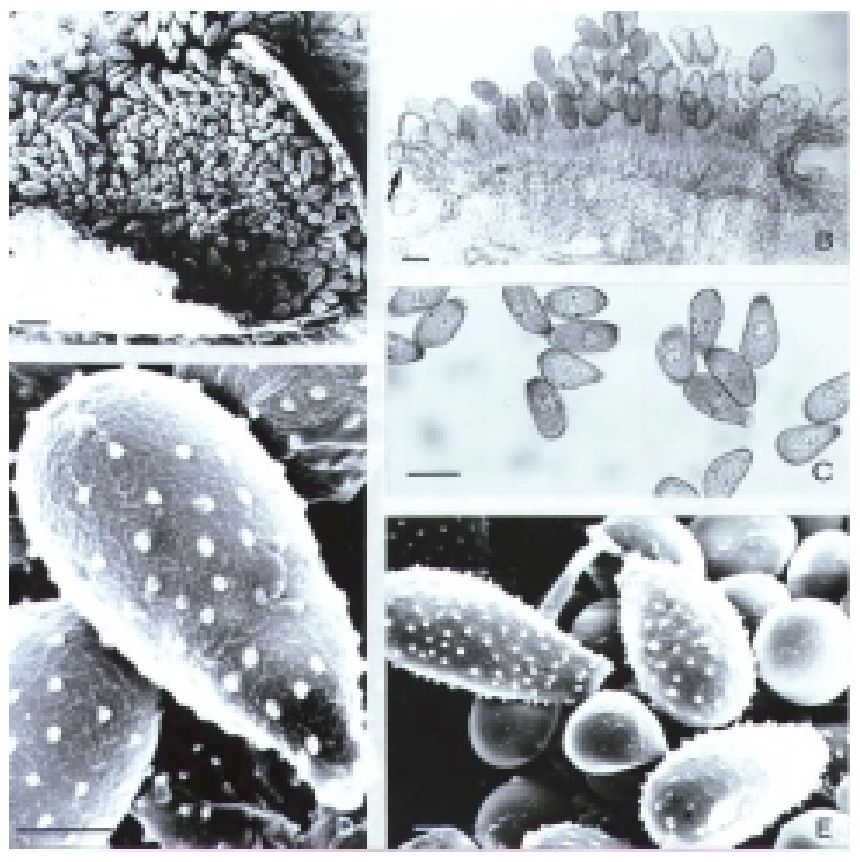

FIG. 7 - Ravenelia emaensis on Anadenanthera sp., uredinial phase. A-Hyphophyllous subepidermal erumpent uredium. B- Setion through an uredinium showing smooth clavate peripheral paraphyses (arrow) and urediniospores. CUrediniospores showing equatorial germ pores. $D$ and E- Clavate urediniospores showing cylindrical to verrucose ornaments. Bars: A, B, and $C=20 \mu \mathrm{m}$; and $E=5 \mu \mathrm{m}$.
(21-) $23(-26) \times(17-) 19(-21) \mu \mathrm{m}$; marginal cells 1824 , wall $0,5-1,0 \mu \mathrm{m}$ of thickness at sides and 5-6 $\mu \mathrm{m}$ at the spore top, (18-) $23(-27) \times(-10) 14(-17) \mu \mathrm{m}$, (Figures $8 \mathrm{D}, \mathrm{E})$. Cysts $18-24$ corresponding on number to the marginal cells, $18 \times 16 \mu \mathrm{m}$ diam., adherent, non hygrophylous, hyaline. Pedicels compound, with 4-6 hyphal strings, 30x14 $\mu \mathrm{m}$, deciduous (Figures 8E,F).

Other specimen examined: on living leaves of Anadenanthera sp., km 44 on the road to Mineiros from Parque Nacional das Emas, in the right lane near the sign indicating Emaus, Mineiros, Goiás, 12 IV 1997, Pfenning 122, UB Col. Mycol. 14330.

The Ravenelia species which showed a closer relationship with this new species were described in Sydow \& Sydow (1915), Cummins (1978) and listed by Hennen et al. (1982). They show smooth teliospore heads or are either parasitic to Piptadenia or to the Anadenanthera species.

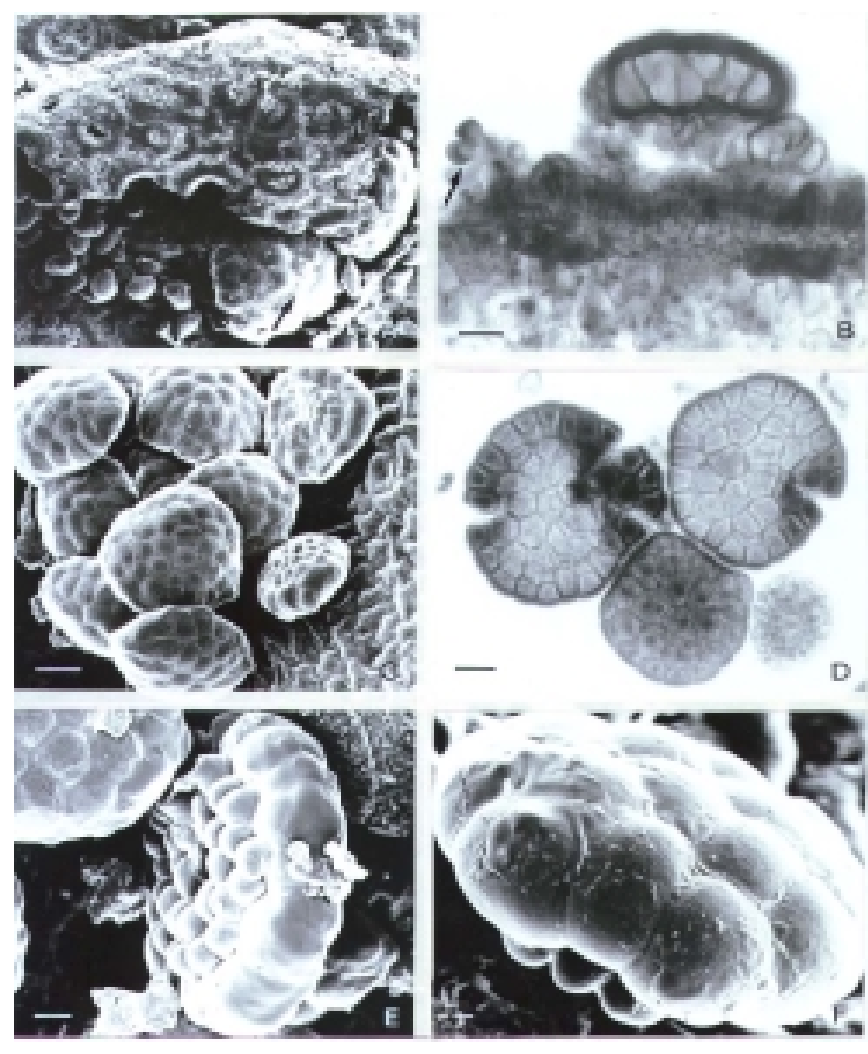

FIG. 8 - Ravenelia emaensis on Anadenanthera sp., telial phase. A- Hipophyllous subepidermal mixed sorus showing two teliospores (arrow) and several ornamented urediniospores. B-Section through a telium showing a teliospore head with adherent cysts and peripheral paraphyses (arrow). C-A group of teliospore heads. D- Teliospore heads seen on OM showing 10-14 central cells and up to 21 marginal cells. $E$ and $F-$ Details of the teliospore head. Bars: $A, B$ and $D=20 \mu \mathrm{m} ; C=$ $30 \mu \mathrm{m} ; \mathrm{E}$ and $\mathrm{F}=10 \mu \mathrm{m}$. 
The new species can be easily separated from all related species (Ravenelia simplex; $R$. henningsiana; $R$. cebil; R. sydowiana; R. spegazziniana; R. chacoensis; Uredo vilis and $R$. mineirosensis) because of the extremely high number of adherent cysts present in its teliospore heads (18 to 24), and due to the formation of uniquely verrugose instead of echinulate urediniospores. The closest species is $R$. sydowiana with 6-19 pendant cysts which also has just 3-5 central cells found in heads (50-85 $\mu \mathrm{m}$ diam.) which, however, are much smaller than those of $R$. emaensis sp. nov. Dimensional and morphological differences also allow to segregate this new species from $R$. mineirosensis $\mathrm{sp}$. nov. which shows only four central cells in the teliospore heads, a number much lower than the 9-12 cells found in $R$. emaensis sp. nov. For these reasons the specimen studied is considered a new Ravenelia species, namely R. emaensis sp. nov.

\section{ACKNOWLEDGMENTS}

The authors express their deep appreciation to Prof. Sônia Nair Báo, head of the Laboratório de Microscopia Eletrônica, Universidade de Brasília, who provided the scanning electron microscope as well as other equipment, facilities and supplies. They also thank the Fundação Banco do Brasil for financially supporting the Project "Fungos do Cerrado".

\section{LITERATURE CITED}

BAXTER, J.W. Notes on Brazilian species of Ravenelia. Mycologia 67:436-437. 1975.

CUMMINS, G.B. Rust Fungi on legumes and composites in North America. Tucson, AZ: Univ. Arizona Press. 1978. CUMMINS, G.B. \& HIRATSUKA, Y. Illustrated Genera of Rust Fungi. Minnesapolis. APS Press. 1983.
DIANESE, J.C., MEDEIROS, R.B., SANTOS, L.T.P., FURLANETTO, C., SANCHEZ, M. \& DIANESE, A.C. 1993. Batistopsora gen. nov. and new Phakopsora, Ravenelia, Cerotellium, and Skierka species from the Brazilian Cerrado. Fitopatologia Brasileira 18:436-450. 1993.

DIANESE, J.C., MEDEIROS, R.B. \& SANTOS, L.T.P. Biodiversity of microfungi found on native plants of the Brazilian Cerrado. In: Kevin D. Hyde (Ed.). Biodiversity of Tropical Microfungi. Hong Kong University Press. 1997. pp. 367-417.

DIETEL, P. Einige newe exotische Pilze. Hedwigia 34:291292. 1895.

HENNEN, J.F. \& CUMMINS, G.B. New species and nomenclature of Ravenelia in Neotropica. Report Tottori Mycological Institute 28:1-14. 1990.

HENNEN, J.F., HENNEN, M.M. \& FIGUEIREDO, M.B. Índice das ferrugens (Uredinales) do Brasil. Arquivos do Instituto Biologico. São Paulo (supl. 1): 1-201. 1982.

LEWIS, G.P. Legumes of Bahia. London. Royal Botanic Garden Kew. 1987.

LINDQUIST, J.C. Três especies nuevas o criticas de ravenelias argentinas. Buletin de la Sociedad Argentina de Botânica 4:298-302. 1946.

MENDONCA, R.C., FELFILI, J.M., WALTER, B.M.T., SILVA Jr. M.C., REZENDE, A.V., FILGUEIRAS, T.S. \& NOGUEIRA, P.E. Flora Vascular do Cerrado. In: Sano, S.M. \& Almeida, S.P. (Eds.) Cerrado: Ambiente e Flora. Brasília. Embrapa 1998. pp. 289-556.

RAJENDREN, R.B. Kernkampella: a new genus of the Uredinales. Mycologia 62:837-843. 1970.

SYDOW, P. \& SYDOW, H. Monografia Uredinearum vol. 3. Leipsig. Fratres Borntraeger. 1915.

SYDOW, P. \& SYDOW, H. Fungi amazonici a cl. E. Ule lecti. Annales Mycologici 14:65-97. 1916. 